\title{
Rational Behavior of an Enterprise in the Energy Market in a Circular Economy
}

\author{
Lazar Gitelman $^{1}$, Elena Magaril ${ }^{2, *} \mathbb{\infty}$, Mikhail Kozhevnikov ${ }^{1}\left(\mathbb{D}\right.$ and Elena Cristina Rada ${ }^{3}$ (D) \\ 1 Department of Management Systems for Energy and Industrial Enterprises, Ural Federal University, \\ Mira str., 19, 620002 Ekaterinburg, Russia; ldgitelman@gmail.com (L.G.); m.v.kozhevnikov@urfu.ru (M.K.) \\ 2 Department of Environmental Economics, Ural Federal University, Mira str., 19, 620002 Ekaterinburg, Russia \\ 3 Department of Theoretical and Applied Sciences, Insubria University of Varese, Via G.B. Vico, 46, \\ 21100 Varese, Italy; Elena.Rada@uninsubria.it \\ * Correspondence: magaril67@mail.ru; Tel.: +7-912-63-98-544
}

Received: 2 March 2019; Accepted: 17 April 2019; Published: 19 April 2019

\begin{abstract}
In order to ensure their market sustainability, it is essential for energy-intensive industrial companies to address the issues of efficient energy use. Companies that are prepared to embrace tariff hikes, structural changes in fuel and energy markets, and a shortage of energy resources have a wider range of options to respond to the new challenges posed by the external environment and to reduce their risks. This task becomes particularly relevant in the context of the development of the circular economy that is aimed at resource optimization, energy conservation, zero-waste manufacturing, and business models that are based on maximum operational efficiency. This study aims to develop a methodology for rational behavior of the energy consumer in the context of the circular economy. The concept of "rational behavior" is defined by the authors as the intention to make the maximum use of the advantages and potential of energy markets in order to reduce the cost of energy supply, increase the level of electrification in industrial production, and use the capabilities of their own energy business. The article describes the main principles of rational behavior that serve as the foundation for effective implementation of various strategies (that of the seller, buyer, or both) in a company. A link is shown between rational behavior and energy market potential management in a company as a mix of technological, economic, and organizational activities performed by the energy consumer in a competitive market and effective market risk management. Forms of off-grid power supply and conditions for their application in manufacturing, for example, mini-combined heat and power $(\mathrm{CHP})$ plants and quadgeneration plants at large metallurgical facilities were analyzed.
\end{abstract}

Keywords: energy market; strategy; rational behavior; circular economy; business model; industrial enterprise; zero-waste production; recovered energy; energy management; energy costs

\section{Introduction}

The transition to a circular economy is a development priority for many countries. For example, China, Finland, Germany, Canada, and Japan are implementing a state policy facilitating such a transition [1-3]. The European Union adopted a roadmap that sets a $60 \%$ reduction target for household solid waste by 2025 [4]. For that sake, a joint European circular economy stakeholder platform was launched [5]. Similar goals are being set for the economy as a whole and for individual industries, with the leading role being given to the energy sector as it both generates and consumes a considerable amount of various waste types. In Estonia and Poland, for example, the energy sector generates around $20 \%$ to $30 \%$ of total waste [6]. Coupled with the mining industry (including fossil energy sources), that amounts to $70 \%$. In Russia, energy and mining sectors account for over $90 \%$ of waste $[7,8]$. 
For the energy sector, including industrial power engineering, the principles of circular economy could be implemented along the following three trajectories [9-12]:

(1) Through closed-loop energy production. In this case, the main "action tactics" include giving priority to renewable energy sources (RES), thorough planning of waste disposal processes, and their application in a repetitive production cycle;

(2) Through forming sustainable cooperation in the chain "energy sector-industry-utilities sector-municipality (region)". In this case, the goal is to optimize energy flows, design mechanisms for minimizing energy losses, and develop distributed generation;

(3) Through integration with end consumers and creation of appropriate innovative business models. From this perspective, the key tasks are to implement demand-side management programs, expand two-sided (platform) markets for electricity and heat, intensify electrification of household and industrial processes, and adopt progressive technologies that provide for better energy efficiency, such as knowledge-intensive services and digital metering, monitoring, and power consumption systems.

The trajectories described above build upon the idea of the transition to zero-waste energy production, which involves the utilization of energy resources in a closed cycle starting with primary raw materials, on to production and consumption, and ending with secondary raw materials (Figure 1). In the context of the first trajectory, it seems reasonable to use the technology of fluidized bed combustion as it increases the generator efficiency, ensures environmental safety of power production, and makes it possible to recycle leftover ash in the production of construction materials. Another option is to minimize waste by creating so-called off-the-grid power systems (Figure 2) that could consist of photovoltaic converters, a small-scale wood-chip-fired combined heat and power (CHP) plant, a diesel power plant, a pellet-burning boiler house, and other equipment $[13,14]$.

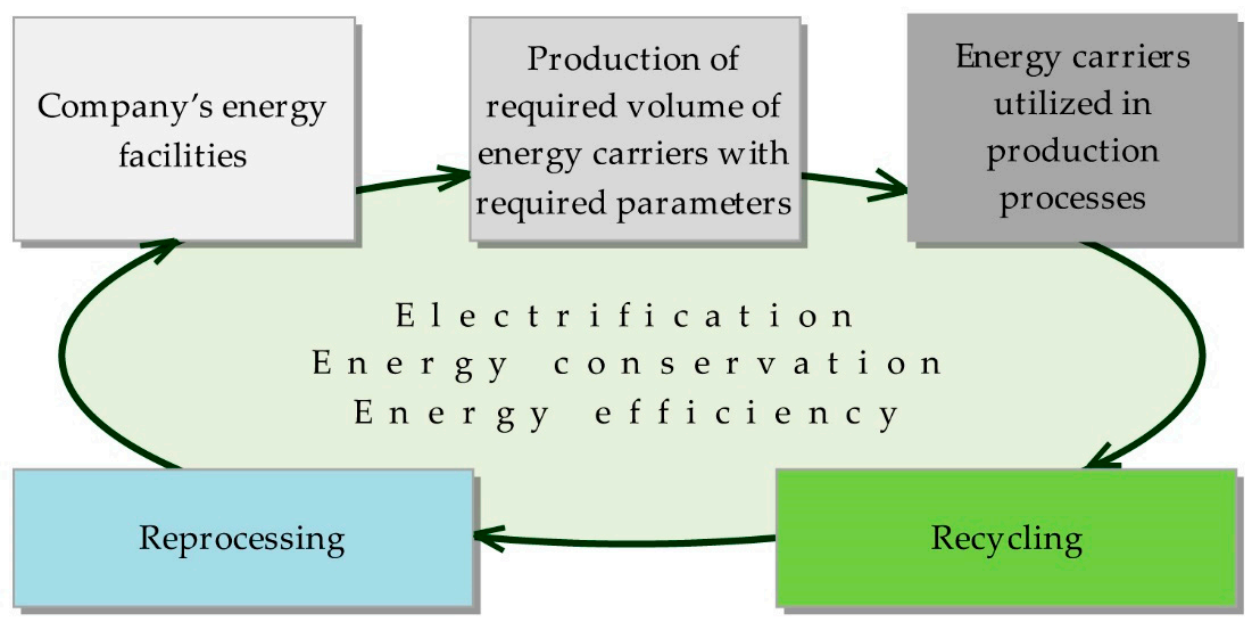

Figure 1. Energy for industrial use in circular economy.

The circular economy, however, necessitates the adoption of near-zero-waste production practices not only at a company level, but within a single eco-system that includes the energy sector, manufacturing, the utilities sector, and end consumers [15,16]. An example of the second trajectory is a neighborhood of Stockholm called Hammarby Sjöstad that was designed and constructed entirely in accordance with the canons of the closed-loop economy [17]. District heating and electricity, water supply, and sewage and waste handling utilities are integrated into a single technological system. Waste heat recovered from the sewage treatment plant, combined with heat issued from a local wood-chip-fired CHP plant, provides district heating. Methane gas from wastewater is processed into cooking and vehicular fuel, while its residual sludge reverts to fertilize the forest. 
Another example is an industry cluster in Denmark. Drugmaker Novo Nordisk, enzyme producer Novozymes, and DONG Energy, together with Denmark's largest oil refinery, run by Statoil, swap waste and byproducts [18]. Steam from DONG's power station is pumped along pipelines around town to the Novo Nordisk and Novozymes plants where it is used in several processes. The power station's waste-ash and gypsum waste-are moved to a cement company and a plasterboard maker, respectively. Novo Nordisk and Novozymes wastewater is purified for municipal use, while their leftover biomass is converted to fertilizer. Statoil also reduced emissions by turning waste sulfur and nitrogen into fertilizer and they also feed back used water to the power station and a water reservoir.

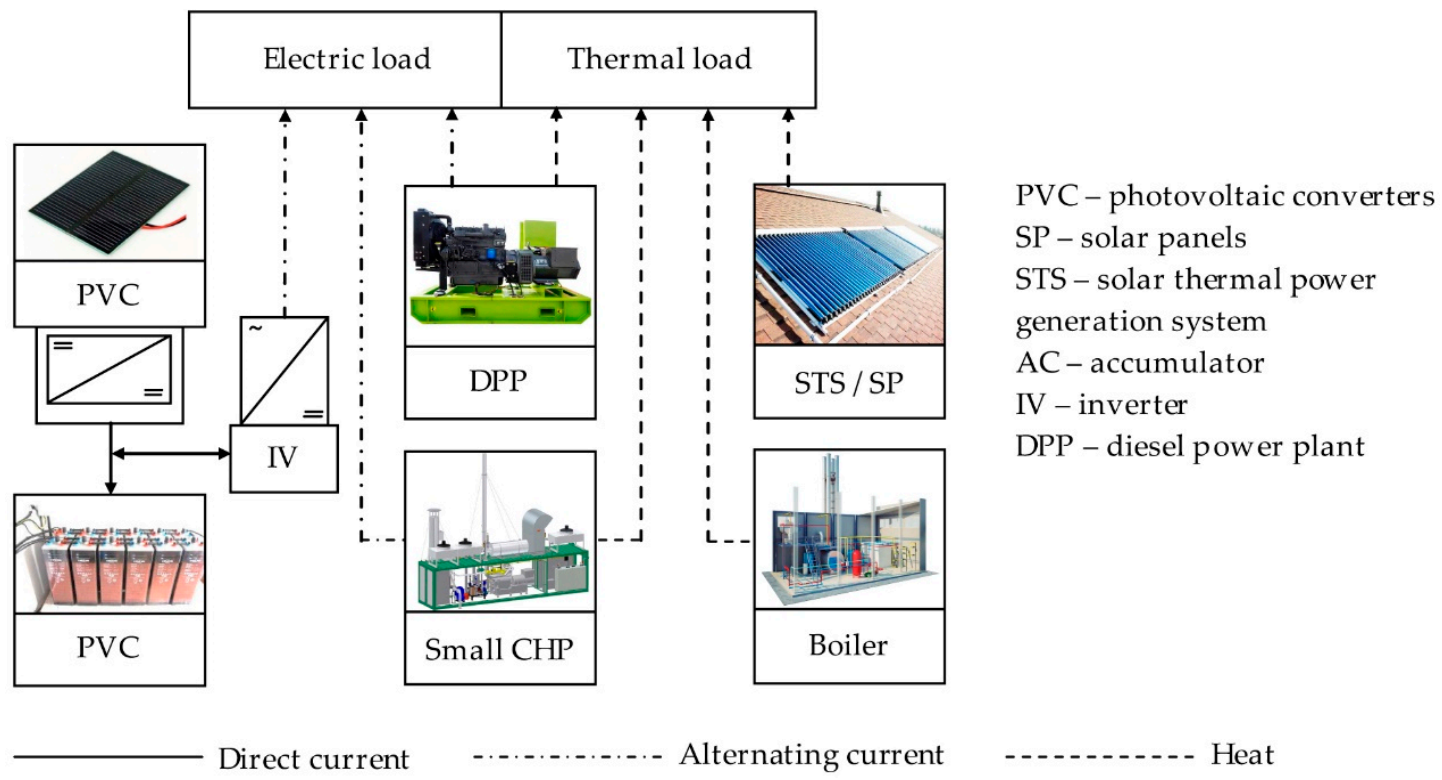

Figure 2. An example of an off-the-grid power supply system at a manufacturing company.

Essential changes to production processes that happen in the context of circular economy lead to a transformation of business models at manufacturing companies (third trajectory). In the transformed models, profits are generated not only by the sale of end products and services, but mostly by means of optimization of material flows and diverse use of resources, materials, and end products for a continuous length of time. The focus of such models is on improving operational efficiency and organizational structures. Variants of such business models in the context of energy business are described in Table 1.

Table 1. Circular business models [19-22].

\begin{tabular}{ccc}
\hline Type & Characteristic & Energy Sector Example \\
\hline Circular value chains & $\begin{array}{c}\text { Replacement of limited resources with } \\
\text { fully renewable ones }\end{array}$ & $\begin{array}{c}\text { Royal DSM created cellulosic bio-ethanol } \\
\text { technology that converts agricultural residue } \\
\text { into renewable fuel }\end{array}$ \\
Recovery and reprocessing & $\begin{array}{c}\text { Using technological capability for } \\
\text { recovery and recycling of resources }\end{array}$ & $\begin{array}{c}\text { Fortum runs circular economy village pilot } \\
\text { projects. In the village, biowaste, plastic, } \\
\text { metals, and fuels are processed to supply } \\
\text { energy to industrial facilities }\end{array}$ \\
\hline Extension of product life cycle & $\begin{array}{c}\text { Extension of economic life of a } \\
\text { product through restoration, repair, } \\
\text { refurbishment, or remarketing }\end{array}$ & $\begin{array}{c}\text { E.On carries out maintenance of energy } \\
\text { equipment on the basis of the state of } \\
\text { generating assets }\end{array}$ \\
\hline
\end{tabular}


Table 1. Cont.

\begin{tabular}{ccc}
\hline Type & Characteristic & Energy Sector Example \\
\hline Exchange and joint consumption & $\begin{array}{c}\text { Platforms for exchanging goods or } \\
\text { assets with low utilization factor; } \\
\text { creation of eco-systems bringing } \\
\text { together manufacturers, } \\
\text { utilities and consumers }\end{array}$ & $\begin{array}{c}\text { The excess heat from Yandex's data center is } \\
\text { collected and fed into the district heating } \\
\text { network in Mäntsälä (Finland); this reduces } \\
\text { Yandex' running costs, overall demand for } \\
\text { fuel for district heating purposes, and carbon } \\
\text { dioxide emissions }\end{array}$ \\
Product as service & $\begin{array}{c}\text { Customers use products by "renting" } \\
\text { it on a pay-per-use basis }\end{array}$ & $\begin{array}{c}\text { Philips retains the right of ownership of the } \\
\text { energy equipment it supplies; customers do } \\
\text { not pay for installation and maintenance as } \\
\text { this constitutes the service part of the contract }\end{array}$ \\
\hline
\end{tabular}

On the one hand, the problem of adaptation of energy arrangements at manufacturing companies to the needs of a circular economy appears quite solvable in terms of technical solutions, many of which were already scientifically investigated and trialed in practice. The list of such solutions includes, first and foremost, measures to eliminate losses of energy carriers, energy recycling, an overall rational approach to energy consumption, and introduction of an energy management system [23-25]. Other areas, however, are less researched. These include ways of fostering the rational behavior of companies in energy markets and principles of creating off-grid power sources. This is mainly due to the cross-disciplinary nature of such studies as they represent an integration of various innovative aspects in the fields of technology, ecology, economics, market strategies, and competence of personnel. At the same time, generalizations applied to industrial power are not sufficiently developed, and the authors' research is devoted to this specific purpose.

The significance of the problem of companies' behavior in energy markets is growing due to the transition to a new energy paradigm that is defined by the development of small-scale generation and microgrids, active expansion of smart grids, transformation of energy and service markets, the emergence of proactive consumers of various nature and, finally, "overall energy hyperconnectivity" [26]. Embracing the circular economy concept, manufacturing companies are becoming active players in the energy market, thus discovering new opportunities for modernization of manufacturing operations and introduction of innovations. The Ellen MacArthur Foundation estimates that this could ensure a 3\% increase in productivity annually $[3,27]$. Moreover, as our research shows, it is precisely these issues that are of the greatest interest to practitioners, both in terms of methodology and promotional tools.

The purpose of this paper is to construct a comprehensive view of the rational behavior of the energy consumer in the framework of a circular economy, to determine basic strategies of manufacturing companies in the energy market and conditions for implementing such strategies effectively.

\section{Materials and Methods}

The research methodology consisted of several stages that made it possible to present approaches to solving the problem of developing energy market strategies for manufacturing companies.

In order to systematize approaches to shaping manufacturing companies' behavior in energy markets, a survey of experts was conducted in the first stage of the research to identify the most "popular" trends and problem areas of zero-waste production management as the priority goal of the circular economy. In the second stage of the research, the authors sought to refine the terminology in order to give more specific definitions to the conceptual aspects of behavior in energy markets. The concept of rational behavior of the energy consumer was introduced; its main principles were explained, along with the structure of the energy market potential of a manufacturing company. The methods that were used in this stage included decomposition, structural, logic, and visual analysis, and conceptual design $[28,29]$. Using the proposed conceptual framework along with content analysis enabled the authors to develop a classification and formulate a methodology for designing an energy market strategy that takes into account both technical and economic features of energy arrangements 
at manufacturing companies operating in various industries, elimination of risks, and utilization of the capabilities of the energy market, as well as justification for creating on-site power generation.

The empirical basis for the research is formed by data harvested from surveys and interviews with the participation of 50 experts, among whom there were heads of energy companies, energy departments at major Russia-based metal companies, chemical companies, and power equipment manufacturers (Table 2). The objectives of the survey were to identify the main directions of the organization of zero-waste production at the enterprises; priority organizational, economic, and technological problems in the transition to zero-waste production and circular economy; formats of work of enterprises in the energy markets; and specific cases for the introduction of advanced energy technologies, including the creation on-site power generation.

Table 2. Pool of respondent enterprises surveyed.

\begin{tabular}{|c|c|c|c|c|}
\hline \multirow{2}{*}{ Company } & \multirow{2}{*}{ Industry } & \multicolumn{2}{|c|}{ Number of Experts Interviewed } & \multirow{2}{*}{$\begin{array}{l}\text { The Proportion of } \\
\text { Respondents by Industry }\end{array}$} \\
\hline & & Top Managers & Line Managers & \\
\hline LLC “Bashkirenergo" & Energy & 2 & 2 & \multirow{4}{*}{$30 \%$} \\
\hline PJSC Gazprom & Energy & 2 & 2 & \\
\hline PJSC “T Plus” & Municipal energy & 2 & 2 & \\
\hline $\begin{array}{c}\text { Municipal Unitary } \\
\text { Enterprise "Vodokanal" }\end{array}$ & Municipal energy & 1 & 2 & \\
\hline LLC “SIEMENS” & $\begin{array}{l}\text { Mechanical } \\
\text { production }\end{array}$ & 1 & 2 & \multirow{4}{*}{$24 \%$} \\
\hline JSC "SINARA-Transport Machines" & $\begin{array}{l}\text { Mechanical } \\
\text { production }\end{array}$ & 1 & 2 & \\
\hline JSC “The Ural Turbine Works” & $\begin{array}{l}\text { Mechanical } \\
\text { production }\end{array}$ & 1 & 2 & \\
\hline JSC “SVEL Group” & $\begin{array}{l}\text { Mechanical } \\
\text { production }\end{array}$ & 1 & 2 & \\
\hline $\begin{array}{l}\text { LLC “Ural Mining Metallurgical } \\
\text { Company” (UMMC) }\end{array}$ & Metallurgy & 2 & 2 & \multirow{4}{*}{$28 \%$} \\
\hline JSC “TMK” & Metallurgy & 2 & 2 & \\
\hline $\begin{array}{l}\text { JSC “EVRAZ Nizhny Tagil } \\
\text { Metallurgical Plant" }\end{array}$ & Metallurgy & 1 & 2 & \\
\hline $\begin{array}{l}\text { PJSC Novolipetsk Iron and Steel } \\
\text { Works (NLMK Group) }\end{array}$ & Metallurgy & 1 & 2 & \\
\hline LLC LUKOIL-Permnefteorgsintez & Chemical industry & 1 & 2 & \multirow{3}{*}{$18 \%$} \\
\hline $\begin{array}{l}\text { PJSC “Ural Rubber Technical } \\
\text { Products Plant” }\end{array}$ & Chemical industry & 1 & 2 & \\
\hline LLC “SIBUR TOBOLSK” & Chemical industry & 1 & 2 & \\
\hline Total & & 20 & 30 & $100 \%$ \\
\hline
\end{tabular}

\section{Results and Discussion}

\subsection{Main Approaches to Zero-Waste Production Management in Industrial Energy Use}

The conducted survey made it possible to identify the most common and "less popular" problem-prone areas in the development of zero-waste energy production in manufacturing. The use of recovered energy and reduction of energy losses under load conditions and in distribution lines could be classified as category one. One of the problem-prone areas is the process of decision-making on entering energy markets (Figure 3).

According to the experts who took part in the survey, the use of recovered energy that constitutes companies' own internal sources of fuel and energy in today's conditions makes it possible to "minimize market price risks in a situation of externally supplied energy", "to improve the reliability and flexibility of power supply", "to increase the economic and energy efficiency of the core technological processes", 
"to improve environmental sustainability", "to make the fuel and energy balance of the company more rational", and "to cut overall energy costs".

\title{
What does you company do to become a zero-waste manufacturer?
}

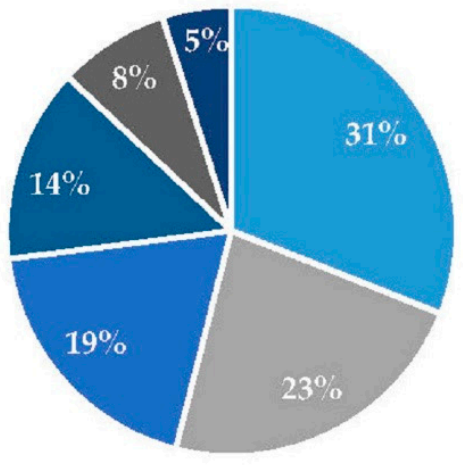

\author{
- Waste energy recovery \\ Efforts to reduce energy losses \\ - Creation of energy management system \\ - Scheduled energy audits \\ - Use of green energy technologies \\ - Creation of company's own energy sources
}

\begin{abstract}
What is your company's main issue in the context of transition to zero-waste production and promotion of the circular economy?
\end{abstract}

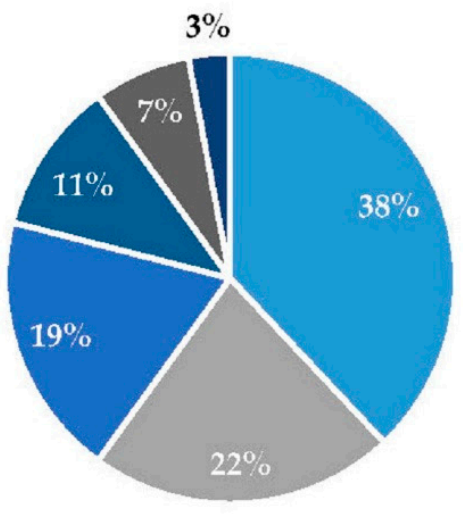

- The mechanism of operating in energy markets is not clear

m The company's status in the value chain is not obvious

- The legislative system is imperfect, limiting the range of possible efforts

- The tendering system for procurement is not perfect, which reduces the efficiency of energy production

- Lack of access to the newest energy technologies

- Insufficient development of the energy service market

Figure 3. Survey results.

Empirical data confirm the popularity of this approach with manufacturing companies; starting from 2014, the global waste-to-energy market expanded at 5\% a year, which is the fastest growth compared to other zero-waste technologies [30,31].

The most commonly used source of recovered energy is blast furnace gas. When burnt, it can cover $35 \%$ to $45 \%$ of heat demand in the energy balance of metals companies [32]. The second most important (after blast furnace gas) source of carbon monoxide at iron and steel companies is converter gas [32]. For example, at a large ironworks with an output of 7 million tons of raw steel a year, around 570 million tons a year of converter gas is generated, which is the equivalent of $130 \mathrm{~m}^{3}$ of natural gas (the latter's calorific value being $40 \mathrm{MJ} / \mathrm{m}^{3}$ ). Consequently, per ton of steel that is produced, converter gases are released that are equal to $17-20 \mathrm{~m}^{3}$ of natural gas [33]. The third major combustible source of recoverable waste energy is coking oven gas. In Japan, for example, the total use of coke gas amounts to 10 billion $\mathrm{m}^{3}$ of coking oven gas used annually, of which $22 \%$ is burnt in coking ovens, $56 \%$ is used in metals production, $10 \%$ is burnt in municipal heating systems, $8 \%$ is used at CHP plants, etc. Coking gas is also commonly used to power gas turbine combined cycle plants [34-37].

The manufacturing companies differ in their energy recovery capacity and the structure of their waste-to-energy potential. This is due to technological features of production, as well as economic factors [38,39]. In some production processes, waste-to-energy units are bundled into the technological process (for example, in oxygen steelmaking). 
The efficiency of energy recovery also strongly depends on the operation cycles of machines and mechanisms generating waste energy. This is partly the reason why the utilization of waste energy is fairly low in the machinery industry [40].

In general, the practice of designing and calculating economic justification for energy recovery installations, as well as their actual performance, shows that they produce significant efficiency gains. For example, the cost of "fuelless" steam that is generated by exhaust heat boilers is half the cost of the steam produced by CHP plants. The efficiency of investment in energy recycling is two to three times higher than in the conventional fuel and energy industry. The most important outcome of energy recovery is the saving of primary energy carriers. This is the main determining factor of the obtained economic effect from the perspective of the circular economy.

Many of the companies analyzed by the authors constructed their own small-scale CHP plants and on-site generators as part of programs aimed at improving energy efficiency and zero-waste production. By doing so, they seek to realize a dual goal of reducing the cost of prime production and going off the grid. Companies that possess big potential in terms of recyclable resources find themselves in the most favorable situation.

For example, on-site electricity produced by Russia's Magnitogorsk Iron and Steel Works is 2.5 times cheaper than the market price because the company-owned power plants utilize blast furnace gas, coke-oven gas, and other secondary energy sources, while transmission costs are minimal [41]. Novolipetsk Iron and Steel Works recycle furnace blast gas and coke-oven gas to power a waste-to-energy 150-MW and a 24-MW top-pressure recovery turbine plant consisting of two pressure recovery turbines as part of its "green" energy strategy. The facilities brought the share of own-generated electricity in the company's total consumption in 2016 to 54\% [42]. EVRAZ Nizhny Tagil Metallurgical Plant implemented a project to utilize a previously unused resource-converter gas—-for generating steam in heat recovery boilers. This makes it possible to heat return water in the district heating network. By installing the heat recovery equipment, the company was able to considerably reduce the consumption of natural gas, thus improving the ecological footprint of generation and minimizing water loss and waste of chemical water treatment.

It has to be noted that the attitude of businesses to specific processes of the actual implementation of the above trends evolves in line with the economic situation and emergence of new technologies. For example, the cost of adding heat recovery equipment on the existing technologies in the iron and steel industry might sometimes prove higher than core production costs.

Substantial and easily adoptable reserves for increasing resource efficiency can also be found in conventional technologies. For example, energy losses occur in all elements of the energy technological system, but the cost of eliminating them varies significantly. In this context, it is advisable to start energy-economic analysis of the system starting from the end stage of the technological process because the lowest-cost energy-saving options are usually hidden in the process load.

Losses in distribution lines can also be substantial. For example, many manufacturing companies typically sustain considerable heat losses in poorly insulated pipelines that lead to units using steam at different pressure. There are also leaks from flange joins, threaded connections, etc. By detecting the above sources of losses, it is possible to considerably reduce fuel and electricity consumption at the company's boiler house and cut back on bills for externally supplied heat.

Despite the relatively strong "popularity" of this approach among the respondents, loss elimination measures often prove too complicated a task. As a rule, the main difficulties stem from an ineffective manufacturing culture that is still typical of the majority of developing countries [37,43]. Consequently, it might be reasonable to recommend that a manufacturing company fine-tunes its system of energy management first and then moves on to implementing specific measures in the field of zero-waste production [44]. 


\subsection{Authors' Definition of the Concept "Rational Behavior of the Energy Consumer"}

There are several currently relevant tasks energy managers at manufacturing companies need to address both from the methodological and practical points of view. The priority for most of them is to minimize current expenditures on fuel and energy carriers, to design mechanisms for reducing the energy intensity of production, and cost management. More complex tasks are associated with the development of rational behavior when taking part in operation in energy markets, construction of appropriate energy market strategies, and making strategic decisions by the owners on creating the company's own energy sources. The tasks could be solved within the framework of various approaches to energy cost management (Table 3).

Table 3. Methodological approaches to energy cost management in manufacturing.

\begin{tabular}{|c|c|c|}
\hline Approach & Conditions of Use & Peculiarities \\
\hline Optimization of energy costs & $\begin{array}{l}\text { - High degree of competition in } \\
\text { main markets } \\
\text { Uncertainty about energy prices and } \\
\text { energy market trends } \\
\text { - Main efforts are aimed at general energy } \\
\text { conservation and higher energy } \\
\text { efficiency of production, introduction of } \\
\text { new technology, expansion } \\
\text { of electrification }\end{array}$ & $\begin{array}{l}\text { Energy costs might be higher as } \\
\text { compared to the first approach, } \\
\text { but opportunities emerge for the } \\
\text { company's technical development and } \\
\text { diversification of its energy business. }\end{array}$ \\
\hline
\end{tabular}

The approach based on energy cost minimization limits opportunities for the company's technical development, which means its efficiency will be frozen at the current level. This does not apply to extremely energy-intensive production facilities where electrification reaches the upper limit. In that case, cost minimization is the only possible option. The implementation of the more advanced concept of energy cost optimization implies that the consumer is able to look for and freely choose among energy supply options, based on prices of energy carriers, energy suppliers, and various ancillary services.

Companies' action strategy is built on the principles of rational behavior that the authors define as "seeking to make the maximum use of advantages and capabilities of energy markets in order to cut energy costs, increase the level of the electrification of manufacturing, and develop its own energy business while minimizing associated threats and risks". The principles are as follows:

1. Motivation to cut (optimize) energy costs. Different consumers will tend to behave in a certain way in energy markets depending on the power of their motivation to be proactive. It has to be observed that positioning oneself as a knowledgeable consumer who operates as an independent buyer in the wholesale market (proactive type of behavior) or as a customer of an energy provider (passive type of behavior) does not mean by itself that measures aimed rationalization of energy processes and zero-waste management will prove ineffective. Such positioning could be prescribed by the technical characteristics of the consumer [45].

2. Monitoring of the company's own energy market potential. Energy market potential describes the technical, economic, and organizational prerequisites for maneuvering in a competitive market and effective management of market risks by the consumer. The concept and the 
corresponding characteristic property of a company need to be introduced in order to determine the market status of the consumer, motivation to reduce energy costs and engage in energy business, the preparedness of energy managers to operate proactively in markets, and priority market strategies.

Table 4 presents the constituents of the potential, the corresponding indicators, and areas of their application. For example, energy-technological potential reflects a company's capability of generating off-the-grid power; economic potential indicates the factor of motivation; organizational potential reflects the quality and energy management-its willingness to change.

Table 4. Structure of energy market potential of a manufacturing company.

\begin{tabular}{|c|c|c|}
\hline Potential & Indicators and Characteristics & Application Area \\
\hline Energy technology & $\begin{array}{ll}\text { - } & \text { Connected capacity } \\
\text { - } & \text { Energy intensity of production } \\
\text { - } & \text { Structure of energy consumption } \\
\text { - } & \text { Energy recovery potential } \\
\text { - } & \text { Regulatory capacity of electric } \\
& \text { machinery and installations }\end{array}$ & $\begin{array}{l}\text { - } \quad \text { Determines the status of the consumer } \\
\text { - } \quad \text { Indicator of the significance of energy } \\
\text { costs for core business } \\
\text { - } \quad \text { Choice of priority energy carriers } \\
\text { - Assessment of off-the-grid power } \\
\text { - } \begin{array}{l}\text { Indicates the expediency of } \\
\text { differentiated electricity rates }\end{array}\end{array}$ \\
\hline Economic & $\begin{array}{l}\text { - } \quad \text { Level of competition in core markets } \\
\text { - } \quad \text { Investment capability } \\
\text { - } \quad \text { Financial standing }\end{array}$ & $\begin{array}{l}\text { Evaluation of motivation to reduce } \\
\text { energy costs } \\
\text { - } \quad \text { Possibility of self-sufficient power } \\
\text { supply; prospects of energy business } \\
\text { - } \quad \text { Determines the status of the consumer }\end{array}$ \\
\hline Organization & $\begin{array}{l}\text { - Availability of energy use data } \\
\text { collection devices } \\
\text { - } \quad \begin{array}{l}\text { Degree of development of energy } \\
\text { management structure }\end{array} \\
\text { - } \quad \begin{array}{l}\text { Reserves for low-cost } \\
\text { energy conservation }\end{array}\end{array}$ & $\begin{array}{l}\text { - Determines the status of the consumer } \\
\text { Evaluation of the preparedness of } \\
\text { energy managers to operate in } \\
\text { energy markets }\end{array}$ \\
\hline
\end{tabular}

It is possible to draw the conclusion that the stronger the energy market potential of a company is, the more room for action and the wider choice of market strategies and their combinations it has, while its strategic management becomes more adaptive.

3. Flexible positioning in energy markets and active search for effective suppliers. The principle implies that, for successful operation in electric power markets, energy managers must have appropriate competencies. More specifically, they must have knowledge in pricing principles that apply in the regulated and competitive sectors of the energy market, the types of services that are provided by energy service companies and utilities, modern methods of price risk management, technical and economic foundations of hybrid power supply, electrification of manufacturing and ways of improving the energy efficiency of manufacturing, and the main types of advanced electric power installations for self-sustained power supply [46-48].

\subsection{Methodological Approaches to Defining the Energy Market Strategy of a Company}

The problem of developing energy market strategies for manufacturing companies is particularly complex due to technical and economic peculiarities of energy arrangements and uncertainty in the future development of the industrial sector, such as the following:

(a) A rigid link with the core technological processes, for example, in metallurgy, machine building, and petrochemical production in terms of the following: 
- The types, volume and parameters of products (steam, hot water, compressed air, oxygen);

- Production modes;

(b) Correspondence between the composition of energy facilities and the technological structure of core production in terms of the following:

- Heat-generating equipment (CHP plants, boiler houses);

- Type and quantity of company-run substations;

- Waste energy recovery equipment (heat recovery boilers, steam accumulators, gas-holders, etc.);

(c) Dependence on the efficiency and characteristics of electrification (for example, replacement of plasma arc or melting furnaces, as well as kilns, with electrical ones);

(d) Backing up of heat-generating units at company-run boiler houses and at CHP plants (for example, boilers or standby steam boilers).

Consequently, the strategy for industrial on-site power generation and energy use (especially regarding capacity expansion) is pegged to the growth strategy for core production. It can, however, have its own strategic goals that reflect areas such as reliability, energy efficiency, or the format of participation in energy markets.

The authors define energy market strategy as a tool of implementing the principle of "rational behavior". This tool is of practical value for the energy management of enterprises in determining the direction of actions to use the opportunities of the energy market that have different options and scenarios (Figure 4).

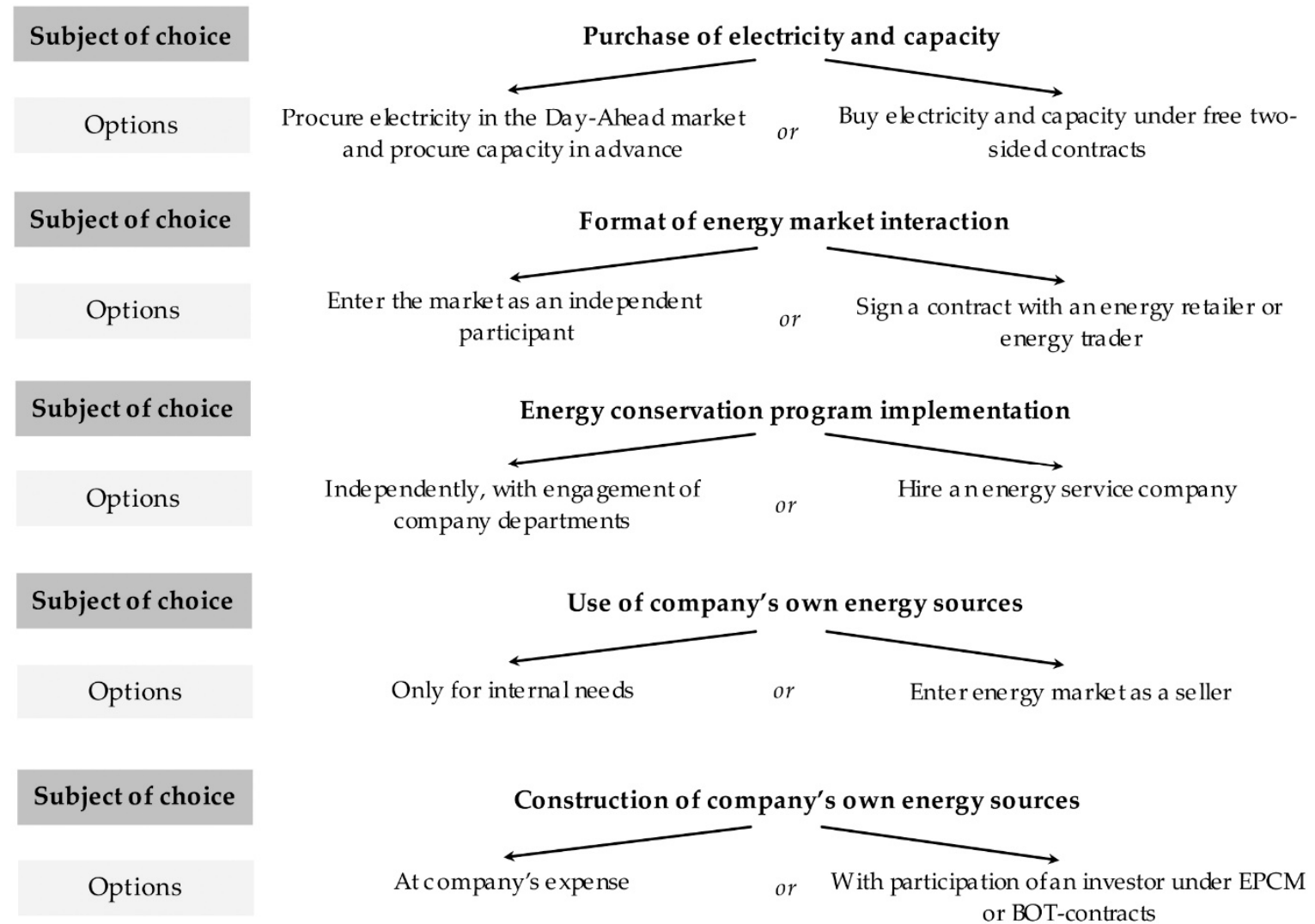

Figure 4. Range of strategic choices for a company considering operating in energy markets.

There are three basic strategies that can be identified for different companies. The following strategies reflect the above principles of rational behavior in energy markets:

(1) Strategy of the buyer; 
(2) Strategy of the seller;

(3) Combined strategy.

The choice of a strategy is influenced by the technical and economic peculiarities of the energy arrangements at companies.

Strategy of the buyer (Figure 5). This strategy can be conventionally designated as "price search strategy". It is suitable for companies that do not have their own power-generating installations and are not going to acquire them, or when the available generators only meet part of the demand for electric power.

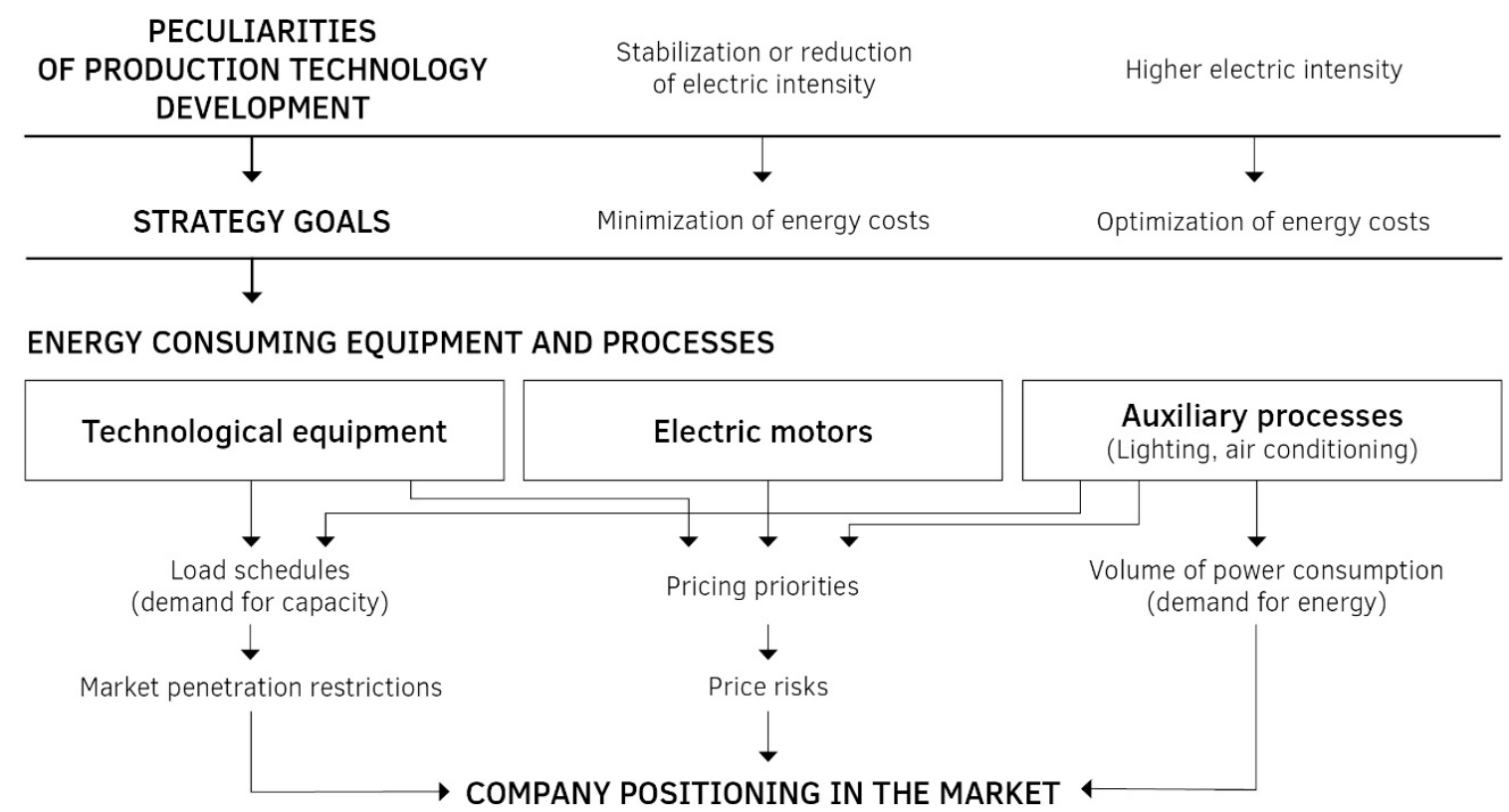

Figure 5. Strategy of the buyer ("price search strategy").

The technology employed by some manufacturing companies (for example, in electrometallurgy) determines the high energy intensity of production and the levels of electrification of industrial processes that are close to the upper limits. In that case, the strategic goal is to "minimize energy costs" by improving energy efficiency and choosing an optimal price of electricity on the basis of the technical and commercial reliability of suppliers and with the goal of encouraging energy conservation. At the same time, it is inexpedient in terms of the competitiveness of costs to try to get the lowest price if there are reserves for saving electricity in the processes where it is the only energy option. That would block investments in rationalizing energy arrangements at such production facilities. The ultimate decision has to be guided by the considerations of economic effectiveness and ensuring the required degree of reliability of power supply.

Other companies have technical and economic opportunities for using alternative energy carriers and increase the level of the electrification of industrial processes by replacing quality fuel with electricity (for example, in high-temperature processes in mechanical production). The natural result of exercising these options will be an increase in the ratio of energy costs to total production costs. On other hand, the integrated effect of electrification will yield a reduction in other elements of costs, higher equipment productivity, and better quality. As a result, the overall economic effectiveness of production grows.

This case matches a strategic goal that can be described as "optimization of energy costs" when the purpose of searching for a better price is to increase the economic competitiveness of electric power in comparison to the energy carrier being replaced (most often natural gas). This means that the upper limit for the electricity price will be determined by natural gas prices; thus, searching for the lowest possible price of electric power in order to meet the goal is quite reasonable. 
Demand for electric power at a manufacturing company can be divided into three blocks that each cover specific consumers: groups of energy-consuming equipment and processes. Consequently, the strategic goals of the buyer will differ in relation to individual energy-consuming processes. For example, cost optimization matches the peculiarities of technology-determined consumption that allows for electrification expansion (for example, furnaces can be powered by both electricity and gas). In this case, it is desirable to receive electricity at a stably low price. The goal of cost minimization applies to electrical equipment and lighting, as electricity is practically the no-alternative energy carrier powering them; hence, higher prices generally encourage power conservation.

The "blocking" method proposed within the framework of the strategy of the buyer allows for well-grounded planning of demand for capacity and electricity, and to formulate case-specific requirements to price limits and associated risks.

Strategy of the seller. The conventional name of the strategy is "energy business". The following business processes are designed within the framework of the strategy:

- Generation and sale of electricity (capacity) in a retail and wholesale market;

- Generation and sale of heat (capacity) in local markets;

- Provision of technological services in a wholesale electricity market (under a contract with the grid operator).

In order to engage in energy business, a company needs to have unused (excess) generating capacity. The capacity might emerge as a result of a cut in the company's own energy consumption thanks to energy-saving measures and ensuing changes in the company's output and product range. Excess capacity also appears as a result of converting boiler houses into steam turbine plants and the renovation of on-site gas turbine power plants that are converted into CHP plants. Both main and backup equipment could be used as commercial energy sources. Only large corporations can afford to construct a high-capacity CHP plant specifically for its energy business or to buy a stake in a large power plant, as they possess the necessary investment and financial resources, and have access to cheap fossil fuels (for example, major oil- and gas-producing companies) [48].

When pursuing this strategy, one needs to remember that the competitiveness of an industrial CHP plant in heat and electricity markets is determined by a number of factors [49]. The first factor is the technical and economic characteristics of generators, gas turbines, and combined cycle installations being recognized as leaders in this regard. The second factor is fuel prices and the ratio between market prices of electricity and market prices of natural gas. Together, these two factors form the gross revenue that a CHP plant must generate as a business-driven project. Thirdly, it is necessary to provide accurate substantiation for the selling price at which both energy carriers will be offered. That will require effective price marketing arrangements and a method of distributing indirect costs of running the CHP plant. The method should be in line with the current market conditions. Another important factor is the cost of heat and the existence of potential buyers of thermal energy.

Combined strategy (Figure 6). The strategy is named "regulatory consumer". A company that pursues the strategy buys electricity (capacity) in different markets and also offers and supplies its regulatory resource in the technology services market. Two schemes could be activated within the framework of the strategy: one involving controllable sets and another one utilizing backup generators for meeting peak demand.

Flexible controllable units (for example, ferroalloy furnaces) must have the technical capability to shed the load during peak hours (up to complete stoppage) without any damage to the quality of products. During night hours, they operate in a boost mode. The regulatory potential of the company's flexible equipment might be demanded by the grid operator, for example, when there is insufficient balance of generating capacity in the grid, a shortage of peak-hour capacity, etc. Additionally, such services will be paid for by the market operator at set prices (later at bid prices), and the providing company will be exempt from a charge for maintaining reserve capacity that is usually included in the electricity price. 


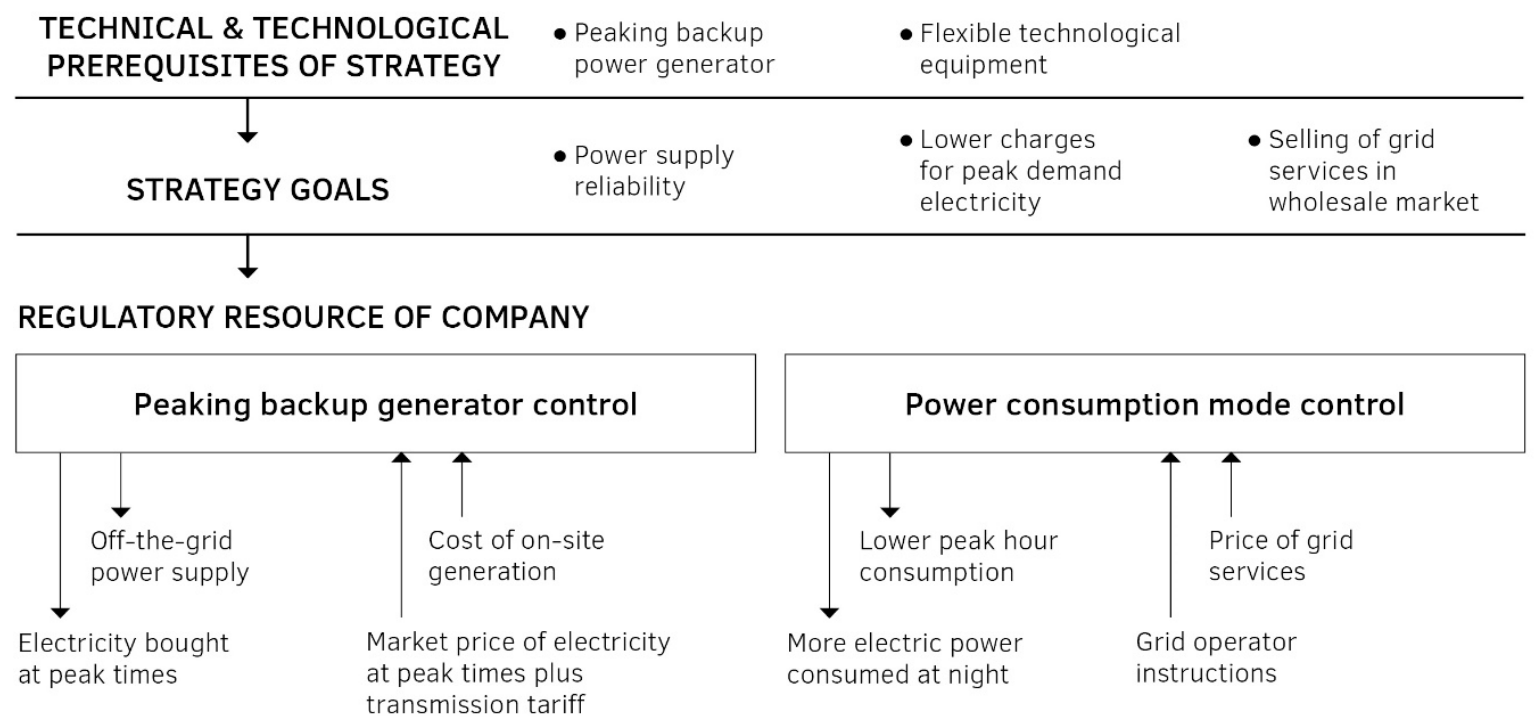

Figure 6. Combined strategy "regulatory consumer".

\subsection{Construction of Company's Own Energy Sources}

A company's decision to go completely or partially off the grid and to start using its own energy source could be viewed as a kind of consumer choice and a response to economic threats and risks generated by energy markets $[50,51]$. The company may change its market status by turning from a buyer to a seller if its generating units operate in parallel with the energy system and supply excess energy and capacity (electric power and thermal energy) to the regional grid.

The expert survey conducted by the authors showed that manufacturing companies were guided by the following motivations when they constructed on-site generators:

- Growing or unstable prices of electricity and heat;

- Development of renewable energy sources and small-scale generation, along with a decrease in the cost of RES equipment and technologies. For example, the price of a standard photovoltaic module in the world decreased tenfold over the past decade, while the total capacity of photovoltaic (PV) systems increased 15 times between 2008 and 2018 (Figure 7). Expert assessments of the so-called levelized cost of electricity from renewables are consistently indicating that the cost of electricity production from renewables is near that of electricity generated by means of conventional technologies [52-54];

- The external source of electricity supply does not meet the reliability requirements of the consumer;

- Technical restrictions on connection of new consumers to the grid.

There are also internal prerequisites, such as high electric power and thermal energy intensity of production, the availability of the company's own cheap fuel (recovered energy, production waste, secondary fuels), strong incentives to reduce energy costs, and the company's investment capabilities. That leads one to a conclusion that even strong external motivating factors may fail to encourage every single consumer to fully switch over to off-the-grid energy sources unless it has the actual means and capability to do that.

There are various forms of stand-alone power supply. They differ by the degree of their independence from external energy supply, type of generator, economic efficiency, and their compatibility with the baseline characteristics of consumers and energy market parameters (Table 5). 


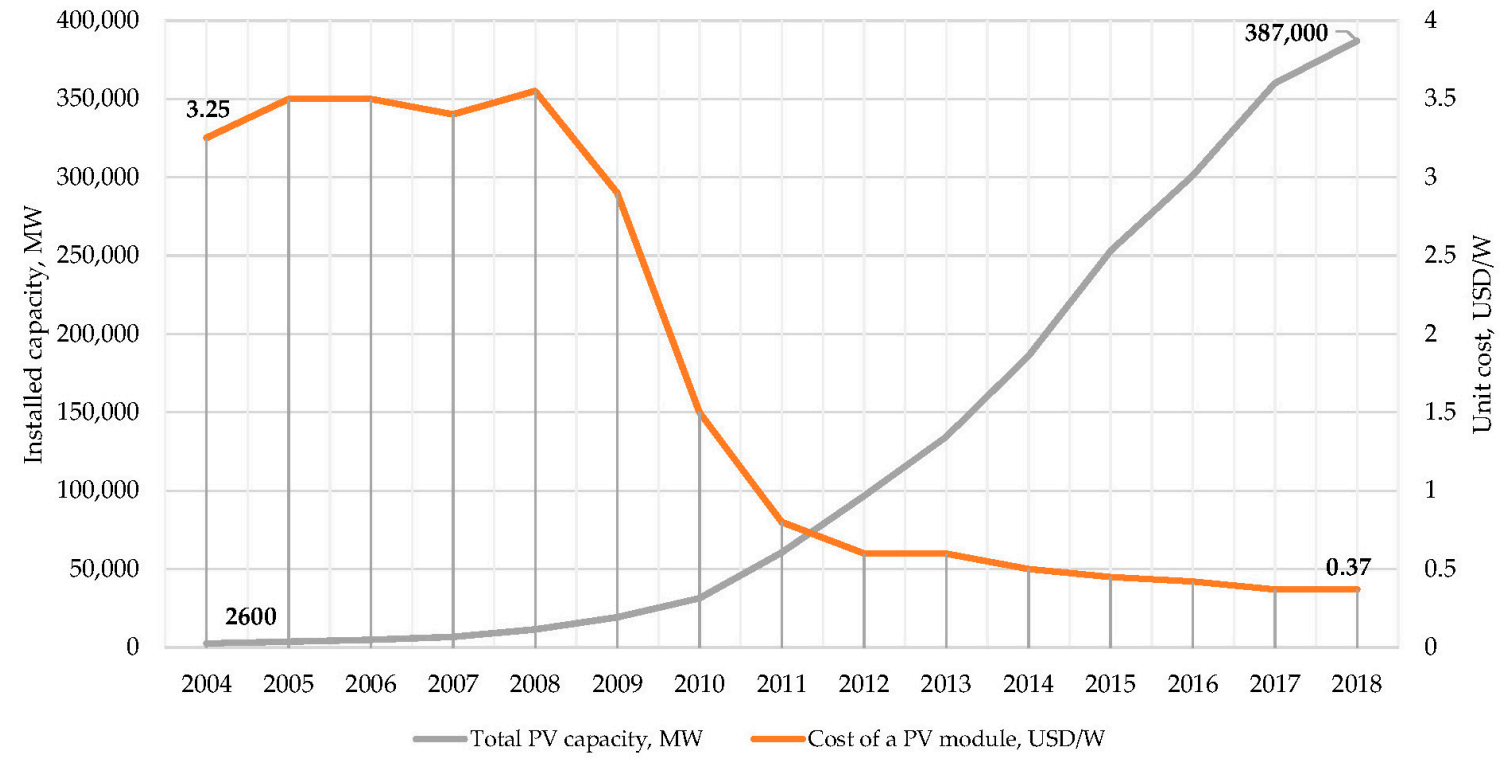

Figure 7. Growth of photovoltaics: ratio of installed capacity and cost of cells.

Table 5. Forms of self-sufficient power supply and conditions for their application at manufacturing companies.

\begin{tabular}{|c|c|c|c|c|}
\hline $\begin{array}{c}\text { Form of Power } \\
\text { Supply }\end{array}$ & $\begin{array}{l}\text { Consumption } \\
\text { Characteristics }\end{array}$ & $\begin{array}{l}\text { Energy Market } \\
\text { Characteristics }\end{array}$ & Type of Installation & Outcomes \\
\hline $\begin{array}{l}\text { Combined } \\
\text { generation of } \\
\text { electric and } \\
\text { thermal energy } \\
\text { (cogeneration) }\end{array}$ & $\begin{array}{l}\text { High electric and } \\
\text { thermal intensity of } \\
\text { production; } \\
\text { round-the-year } \\
\text { constant heat load; } \\
\text { access to cheap } \\
\text { energy resources }\end{array}$ & $\begin{array}{l}\text { High prices of } \\
\text { electric and } \\
\text { thermal energy; } \\
\text { low prices of } \\
\text { natural gas; } \\
\text { restrictions on new } \\
\text { grid connections }\end{array}$ & $\begin{array}{l}\text { Gas-turbine combined } \\
\text { heat and power }(\mathrm{CHP}) \\
\text { plants, small steam units } \\
\text { with coefficient of } \\
\text { performance }(\mathrm{COP}) \approx 90 \% \text {; } \\
\text { energy-recovering units }\end{array}$ & $\begin{array}{c}\text { Lower energy costs; } \\
\text { income from selling excess } \\
\text { energy (capacity); } \\
\text { launch of new } \\
\text { production capacity }\end{array}$ \\
\hline Peak-load coverage & $\begin{array}{l}\text { High load at peak } \\
\text { times; electricity } \\
\text { consumption mode } \\
\text { cannot be changed }\end{array}$ & $\begin{array}{l}\text { High prices during } \\
\text { peak hours; } \\
\text { restrictions on } \\
\text { power supply } \\
\text { during peak hours }\end{array}$ & $\begin{array}{l}\text { Peaking gas turbine units } \\
\text { of various types } \\
\text { (efficiency } \approx 38-40 \% \text { ) }\end{array}$ & $\begin{array}{l}\text { Peak time money saving; } \\
\text { stable power supply } \\
\text { during peak load hours }\end{array}$ \\
\hline $\begin{array}{l}\text { Emergency power } \\
\text { supply }\end{array}$ & $\begin{array}{l}\text { Presence of } \\
\text { responsible power } \\
\text { consumers }\end{array}$ & $\begin{array}{l}\text { High failure rate in } \\
\text { power supply } \\
\text { system }\end{array}$ & $\begin{array}{l}\text { Diesel (multi-fuel) } \\
\text { generators }\end{array}$ & $\begin{array}{l}\text { Elimination (minimization) } \\
\text { of damage from } \\
\text { interrupted power supply }\end{array}$ \\
\hline
\end{tabular}

The following types of energy installations are recommended for decentralized power supply of manufacturing companies:

- Combined-cycle gas turbines and gas-powered generators;

- Small combined-cycle steam power plants with back pressure turbines;

- $\quad$ Peaking gas turbine units (with an efficiency of 38 to $40 \%$ );

- Diesel engine based combined-cycle power plants;

- Peaking and backup diesel engine-based installations;

- Steam and gas turbines for on-site industrial boiler houses (with the option to recover exhaust heat).

Small and medium combined-cycle gas-turbine units ( 0.5 to $20 \mathrm{MW}$ ) are the most attractive option for operation in a baseload mode. They are compact and fairly inexpensive (500 to 600 United States 
dollars (USD)/kW) yet highly efficient (up to 85 to $90 \%$ ). The thermal efficiency of such units will be the highest if the rated capacity of the gas turbine unit matches the guaranteed thermal load of the unit throughout the year [55]. Backup turbine units of industrial CHP plants with high flexibility characteristics can prove economically efficient when used for meeting the system peak load and as a paid-for system emergency reserve. An important prerequisite for the wide application of small- and medium-sized combined-cycle CHP plants is the possibility of adding them onto existing industrial gas-powered boiler houses in case of the renovation, expansion, or modernization of the latter [56,57].

There are a number of configurations of combined-cycle CHP plants with high thermal efficiency and electricity generation capacity at the set thermal input. The simplest and most common one is the thermal scheme that envisages that heat energy is only generated by capturing the heat from exhaust gases in the turbines of gas-cooled heat exchangers (heat recovery boilers, heating or steam boilers).

The installation of small steam turbine generator sets at industrial boiler houses, especially those powered with residual oil and solid fuels, is globally recognized as a highly promising global trend [58]. Turbines work instead of throttling devices-pressure-reducing valves-when the pressure of the passing steam changes in transition between the boiler and extraction for industrial purposes, or the heat exchanger. Installing the turbines in parallel with throttling valves makes it possible to produce electricity that is eight times cheaper than externally sourced electricity. Small steam turbine sets can be used not only for driving generators, but also for propelling generator sets at all types of boiler houses powered by industrial steam. This allows for cutting internal electric power consumption by $70 \%$ to $80 \%$. The replacement of a section of boilers at gas-powered boiler houses with combined-cycle gas turbine units will pursue the same goals.

There are, however, certain performance-related technical issues that hamper the economic efficiency of industrial energy sources utilizing advanced technologies [59]. For example, it can be difficult to ensure that electricity produced at units at small-scale CHP plants operating in stand-alone mode meets the established quality standards [60]. However, it is much easier to do in the case of parallel operation with the grid. The parallel mode increases short-circuit currents in the distribution network that will have to be overhauled at a cost borne by the owner of the small-scale power plant.

Ural Mining and Metallurgical Company (UMMC), a leader of the global metal industry, is an example of a company that actively expands it is own small-scale generation. One of its subsidiaries, Sredneuralsk Copper Smelter (SUMZ), launched a mini-CHP plant consisting of five 4.3-MW gas generator sets manufactured by Motoren WerkeManheim. The generators operate in cogeneration mode producing hot water. The annual electricity output of the mini power plant is 162 million $\mathrm{kWh}$ of thermal energy $(97,000 \mathrm{Gcal})$. The CHP plant enabled SUMZ to not only improve the reliability of power supply at its facilities, to reduce energy costs and increase the energy and environmental safety of production, but it was also a pilot project implemented by UMMC under a build-operate-transfer (BOT) contract, whereby an investor funds the construction of an on-site power generating facility that is then leased to the contractor. The term of the lease is usually equal to the project payback period. When it ends, the facility is transferred into the ownership of the operator.

Another example that fully fits the peculiarities of the circular economy, as well as of industrial digitalization trends, is the construction of a smart energy center to service UMMC's greenhouse complex in Yekaterinburg (Sverdlovsk Region, Russia). The energy center operates in isolation from the local distribution network (island mode). The installed capacity of the energy center is $26.4 \mathrm{MW}$ for electricity and $94.3 \mathrm{Gcal} /$ hour for thermal energy, which meets the energy needs of the greenhouse complex by practically $100 \%$ as energy costs account for up to $50 \%$ to $60 \%$ of the total costs of greenhouse crop production using supplemental lighting. Having a small CHP plant will not only make it possible to minimize expenditure on externally sourced energy, but also to considerably increase crop yield thanks to carbon dioxide recovered from exhaust gases.

The energy center employs a quadgeneration system combining the production of heat, carbon dioxide, power generation, and refrigeration, which is a unique solution as heat is generated in parallel with chill. In addition to the main energy components (electricity and heat), the gas generator set 
of the energy center produces a plant fertilizer-carbon dioxide-thanks to the CoDiNox r Catalytic system. The project also envisages the installation of absorption refrigerators that will eliminate the main drawback of greenhouse complexes that have to use water heaters in the summer to produce carbon dioxide while releasing excess heat into the environment. The UMMC energy center utilizes excess heat in absorption refrigerators for generating chill to air-condition the sorting and packing area.

\section{Conclusions}

High costs of energy production and transmission, unstable energy process, and the urge to switch over to a resource-saving and low-carbon model of business are a source of uncertainty, risks, and problems for companies in terms of efficient energy use. This is particularly relevant to energy-intensive consumers who rely on costly and high-quality energy carriers (gas and electric power) and who operate in a tough competitive environment.

The circular economy sets special requirements for energy management in manufacturing. This, first and foremost, means putting straight energy consumption in order to ensure the maximum conservation of energy down the entire production and process chain. These are purely organizational measures that do not require big investment, but that have great potential in developing countries (improved accounting practices, energy-saving measures in universal processes such as lightning, electric engines, ventilation, heating).

At the same time, the study shows the increasing relevance of a strategic approach to manufacturing companies' behavior in energy markets. In this regard, this study may be of particular interest for developing countries that are in the final stage of energy liberalization, as well as for countries with complex energy market structures.

The conceptual framework that was developed by the authors allows for building a methodological basis of such an approach to energy management and to ensure the participation of specialists from different fields of knowledge and practice in making interdisciplinary decisions. The proposed classification of energy market strategies and areas of their application enables one to make a rational choice of behavior alternatives that match the specific marketing goals of a company. The choice can be made through analyzing the technological peculiarities of production processes, determining the marketing goals of the company, verifying the volume of demand and the structure of demand for (supply of) the company's core products, and the volume of energy that is required for production.

As small-scale generation technologies are getting increasingly advanced, having an on-site energy source is becoming more attractive as an option. Coupled with the penetration of smart technologies in core manufacturing practices and a transition to a new energy paradigm, conditions for comprehensive utilization of reserves of various resources are created.

In this regard, this scientific paper opens up prospects for further research in a number of areas. On that score, the studies of the characteristics of the new stage of electrification determined by the trends of the Fourth Industrial Revolution are relevant, as industrial enterprises are transforming into active consumers interested in implementing energy demand management programs and using new technological opportunities to customize production at a fast pace. Another major scientific task is the definition of competencies and the organization of advanced training of highly qualified specialists and teams to work in the new energy paradigm conditions and markets.

Author Contributions: All authors contributed equally to the present work. Conceptualization and methodology, L.G. and M.K.; formal analysis and investigation, L.G., M.K., and E.M., writing-original draft preparation, M.K.; writing-review and editing, E.M. and E.C.R.; validation and visualization, E.C.R. and M.K.

Funding: This research received no external funding.

Acknowledgments: The work was supported by Act 211 of the Government of the Russian Federation, contract NO. 02.A03.21.0006.

Conflicts of Interest: The authors declare no conflicts of interest. 


\section{Abbreviations}

$\begin{array}{ll}\text { AC } & \text { Accumulator } \\ \text { CHP plant } & \text { Combined heat and power plant } \\ \text { COP } & \text { Coefficient of performance } \\ \text { DPP } & \text { Diesel power plant } \\ \text { IV } & \text { Inverter } \\ \text { RES } & \text { Renewable energy sources } \\ \text { PV } & \text { Photovoltaic } \\ \text { PVC } & \text { Photovoltaic converters } \\ \text { SP } & \text { Solar panels } \\ \text { STS } & \text { Solar thermal power generation system }\end{array}$

\section{References}

1. Ruiz-Real, J.L.; Uribe-Toril, J.; Valenciano, J.D.P.; Gázquez-Abad, J.C. Worldwide research on circular economy and environment: A bibliometric analysis. Int. J. Environ. Res. Public Health 2018, 15, 2699. [CrossRef]

2. Ghisellini, P.; Cialani, C.; Ulgiati, S. A review on circular economy: The expected transition to a balanced interplay of environmental and economic systems. J. Clean. Prod. 2016, 114, 11-32. [CrossRef]

3. Towards the Circular Economy. Economic and Business Rationale for an Accelerated Transition. Ellen Macarthur Foundation. 2013. Available online: https://www.ellenmacarthurfoundation.org/assets/ downloads/publications/Ellen-MacArthur-Foundation-Towards-the-Circular-Economy-vol.1.pdf (accessed on 24 February 2019).

4. Rada, E.C. Special Waste valorization and renewable energy generation under a circular economy: Which priorities? WIT Trans. Ecol. Environ. 2019, 222, 145-157. [CrossRef]

5. European Circular Economy Stakeholder Platform Names Its Coordination Group Members. Available online: https://ec.europa.eu/growth/content/european-circular-economy-stakeholder-platformnames-its-coordination-group-members_fr (accessed on 24 February 2019).

6. Zamparutti, T.; McNeill, A.; Moora, H.; Jõe, M.; Piirsalu, E. Circular Economy with Focus on Waste, Renewable Energy and Sustainable Bioenergy in Estonia. Available online: http://www.europarl.europa.eu/RegData/ etudes/BRIE/2017/602038/IPOL_BRI(2017)602038_EN.pdf (accessed on 24 February 2019).

7. OECD.Stat. Available online: https://stats.oecd.org (accessed on 24 February 2019).

8. Russian Federation Federal State Statistics Service. Available online: http://www.gks.ru/wps/wcm/connect/ rosstat_main/rosstat/en/main/ (accessed on 24 February 2019).

9. Pomponi, F.; Moncaster, A. A Theoretical Framework for Circular Economy Research in the Built Environment. In Building Information Modelling, Building Performance, Design and Smart Construction; Dastbaz, M., Gorse, C., Moncaster, A., Eds.; Springer: Cham, Switzerland, 2017; pp. 31-44. [CrossRef]

10. Gerasimenko, D.; Nikolayeva, I. Circular economy in Russia in the context of the UN Sustainable Development Goals and the Year of Ecology. Bridges 2017, 10. Available online: https://www.ictsd.org/bridges-news (accessed on 24 February 2019).

11. Donia, E.; Mineo, A.M.; Sgroi, F. A methodological approach for assessing businness investments in renewable resources from a circular economy perspective. Land Use Policy 2018, 76, 823-827. [CrossRef]

12. Giezen, M. Shifting infrastructure landscapes in a circular economy: An institutional work analysis of the water and energy sector. Sustainability 2018, 10, 3487. [CrossRef]

13. Marchenko, O.V.; Solomin, S.V. Integrated use of renewable energy sources of different types for combined heat and electricity production. Ind. Energy 2018, 5, 52-57.

14. Panepinto, D.; Zanetti, M.C.; Gitelman, L.; Kozhevnikov, M.; Magaril, E.; Magaril, R. Energy from Biomass for Sustainable Cities. IOP Conf. Ser. Earth Environ. Sci. 2017, 72, 012021. [CrossRef]

15. Albores, P.; Petridis, K.; Dey, P.K. Analysing efficiency of Waste to Energy Systems: Using Data Envelopment Analysis in Municipal Solid Waste Management. Procedia Environ. Sci. 2016, 35, 265-278. [CrossRef]

16. Cioca, L.I.; Ferronato, N.; Viotti, P.; Magaril, E.; Ragazzi, M.; Torretta, V.; Rada, E.C. Risk Assessment in a Materials Recycling Facility: Perspectives for Reducing Operational Issues. Resources 2018, 7, 85. [CrossRef]

17. Brown, H. A Circular Energy Economy: Cross-Sector Successes in Brazil and India. Available online: http://ic-sd.org/wp-content/uploads/sites/4/2018/02/Hillary-Brown.pdf (accessed on 24 February 2019). 
18. Batova, N.; Sachek, P.; Tochitskaya, I. Circular economy in action: Forms of organization and best practices. BEROC Green Econ. Policy Pap. Ser. 2018, 5. Available online: http://eng.beroc.by/research/policy_papers/ge-5/ (accessed on 24 February 2019).

19. Lahti, T.; Wincent, J.; Parida, V. A Definition and Theoretical Review of the Circular Economy, Value Creation, and Sustainable Business Models: Where Are We Now and Where Should Research Move in the Future? Sustainability 2018, 10, 2799. [CrossRef]

20. Lacy, P.; Rutqvist, J. Waste to Wealth. The Circular Economy Advantage; Palgrave Macmillan: Basingstoke, UK, 2015.

21. Gabriel, C.-A.; Kirkwood, J. Business models for model businesses: Lessons from renewable energy entrepreneurs in developing countries. Energy Policy 2016, 95, 336-349. [CrossRef]

22. Circular Advantage: Innovative Business Models and Technologies to Create Value in a World without Limits to Growth. Available online: https://www.accenture.com/t20150523T053139_w_/us-en/_acnmedia/Accenture/ Conversion-Assets/DotCom/Documents/Global/PDF/Strategy_6/Accenture-Circular-Advantage-InnovativeBusinessModels-Technologies-Value-Growth.pdf (accessed on 24 February 2019).

23. Dobrova, K.B.; Danilochkina, N.G.; Cherner, N.V.; Dobrov, V.P.; Dobrov, P.P.; Sepiashvili, E.N. Innovational Management of Industrial Enterprises in the Energy Sector. Eur. Res. Stud. J. 2018, 21, 447-458.

24. Păunescu, C.; Blid, L. Effective energy planning for improving the organization's energy performance. Manag. Mark. Chall. Knowl. Soc. 2016, 11, 513-531. [CrossRef]

25. Ciacci, L.; Vassura, I.; Passarini, F. Shedding Light on the Anthropogenic Europium Cycle in the EU-28. Marking Product Turnover and Energy Progress in the Lighting Sector. Resources 2018, 7, 59. [CrossRef]

26. Semeria, M. Symbiotic Low-Power Smart and Secure Technologies in the Age of Hyperconnectivity. In Proceedings of the IEEE 62nd International Electron Devices Meeting (IEDM), San Francisco, CA, USA, 3-7 December 2016; pp. 9-22. [CrossRef]

27. Gitelman, L.D.; Gitelman, L.M.; Kozhevnikov, M.V. Window of opportunity for sustainable energy. Int. J. Energy Prod. Manag. 2017, 2, 173-185. [CrossRef]

28. Ryzhuk, O.B.; Gitelman, L.D.; Kozhevnikov, M.V.; Bashorina, O.V.; Boyarinov, A.; Buntov, E.A.; Kuzmina, A.V.; Makarova, O.A.; Pishevskaya, E.S.; Polyakova, V.V.; et al. Visual Brainstorming in Concept Project Development in the Power Industry. In Challenges and Solutions in the Russian Energy Sector, Innovation and Discovery in Russian Science and Engineering, Series; Syngellakis, S., Brebbia, C., Gitelman, L.D., Magaril, E.R., Eds.; Springer: Cham, Switzerland, 2018; pp. 243-250. [CrossRef]

29. Gitelman, L.D.; Ryzhuk, O.B.; Kozhevnikov, M.V. Visual analysis for conceptual design of complex systems. Int. J. Des. Nat. Ecodyn. 2018, 13, 166-175. [CrossRef]

30. World Energy Resources: Waste to Energy. Available online: https://www.worldenergy.org/wp-content/ uploads/2017/03/WEResources_Waste_to_Energy_2016.pdf (accessed on 24 February 2019).

31. Themelis, N.J. An overview of the global waste-to-energy industry. Waste Manag. World 2003, 40-47.

32. Mandal, M.K.; Sinha, O.P. Technological Changes in Blast Furnace Iron Making in India since Last Few Decades. Int. J. Sci. Res. 2013, 2, 211-219.

33. Dragna, E.C.; Ioana, A.; Constantin, N. Methods of steel manufacturing-The electric arc furnace. IOP Conf. Ser. Mater. Sci. Eng. 2017, 294, 012017. [CrossRef]

34. Branchini, L. Advanced Waste-to-Energy Cycles. Available online: http://amsdottorato.unibo.it/4696/1/Tesi_ Dottorato_Branchini.pdf (accessed on 24 February 2019).

35. Campos, U.; Zamenian, H.; Koo, D.D.; Goodman, D.W. Waste-to-Energy (WTE) Technology Applications for Municipal Solid Waste (MSW) Treatment in the Urban Environment. Int. J. Emerg. Technol. Adv. Eng. 2015, 5, 504-508.

36. Ionescu, R.D.; Ragazzi, M.; Battisti, L.; Rada, E.C.; Ionescu, G. Potential of electricity generation from renewable energy sources in standard domestic houses. WIT Trans. Ecol. Environ. 2013, 176, 245-253. [CrossRef]

37. Perrot, J.-F.; Subiantoro, A. Municipal Waste Management Strategy Review and Waste-to-Energy Potentials in New Zealand. Sustainability 2018, 10, 3114. [CrossRef]

38. Van Caneghem, J.; De Coster, E.; Vandenbergh, K.; De Broyer, S.; Lambrix, N.; Weemaels, L. Closing the household metal packaging cycle through recovery of scrap from waste-to-energy bottom ash: The case study of Flanders. Resour. Conserv. Recycl. 2019, 144, 115-122. [CrossRef] 
39. Rada, E.C.; Ragazzi, M.; Torretta, V.; Castagna, G.; Adami, L.; Cioca, L.I. Circular economy and waste to energy. AIP Conf. Proc. 2018, 1968, 030050. [CrossRef]

40. World Energy Resources: Waste to Energy. Available online: https:/www.worldenergy.org/wp-content/ uploads/2013/10/WER_2013_7b_Waste_to_Energy.pdf (accessed on 24 February 2019).

41. Magnitogorsk Iron and Steel Works. Annual Report 2015. Available online: http://eng.mmk.ru/upload/ iblock/632/Annual\%20Report_2015.pdf (accessed on 24 February 2019).

42. NLMK Annual Report 2016. Available online: https://nlmk.com/upload/iblock/6da/nlmk-draft-annualreport-2016-eng.pdf (accessed on 24 February 2019).

43. Sheltawy, S.; Al-Sakkari, E.; Fouad, M. Waste to Energy Trends and Prospects: A Review. Available online: https://www.researchgate.net/publication/312137263_Waste_to_Energy_Trends_and_ Prospects_A_Review (accessed on 24 February 2019).

44. Winston, A.; Favaloro, G.; Healy, T. Energy Strategy for the C-Suite. Available online: https://hbr.org/2017/01/ energy-strategy-for-the-c-suite (accessed on 24 February 2019).

45. Perillo, G. Energy Management as Production Input. WIT Trans. Ecol. Environ. 2016, 205, 3-9. [CrossRef]

46. Dudin, M.N.; Reshetov, K.Y.; Mysachenko, V.I.; Mironova, N.N.; Divnenko, O.V. Green Technology and Renewable Energy in the System of the Steel Industry in Europe. Int. J. Energy Econ. Policy 2017, 7, 310-315.

47. Olson, E.G. Creating an enterprise-level "green" strategy. J. Bus. Strategy 2008, 29, 22-30. [CrossRef]

48. Lyaskovskaya, E.A.; Kurbangaliev, M.R. Energy management of industrial enterprise. SHS Web Conf. 2017, 35, 01129. [CrossRef]

49. Simchak, T.; Davis, S. Combined Heat and Power for Industrial Revitalization. Policy Solutions to Overcome Barriers and Foster Greater Deployment. Available online: http://ccap.org/assets/White-Paper_CombinedHeat-and-Power-for-Industrial-Revitalization_CCAP_July-20131.pdf (accessed on 24 February 2019).

50. Tchorzewska-Cieslak, B.; Pietrucha-Urbanik, K.; Urbanik, M.; Rak, J.R. Approaches for Safety Analysis of Gas-Pipeline Functionality in Terms of Failure Occurrence: A Case Study. Energies 2018, 11, 1589. [CrossRef]

51. Tchórzewska-Cieślak, B.; Pietrucha-Urbanik, K. Approaches to Methods of Risk Analysis and Assessment Regarding the Gas Supply to a City. Energies 2018, 11, 3304. [CrossRef]

52. International Energy Outlook 2016. Available online: https://www.eia.gov/outlooks/ieo/pdf/0484(2016).pdf (accessed on 24 February 2019).

53. Dorris, G.; Blanco, C. Navigating the New Energy Market Dynamics. Available online: https://www. ascendanalytics.com/assets/er0218-technical_7.pdf (accessed on 24 February 2019).

54. Candelise, C.; Winskel, M.; Gross, R. The dynamics of solar PV costs and prices as a challenge for technology forecasting. Renew. Sustain. Energy Rev. 2013, 26, 96-107. [CrossRef]

55. Oyedepo, S.O.; Fagbenle, R.O.; Adefila, S.S.; Adavbiele, S.A. Performance evaluation and economic analysis of a gas turbine power plant in Nigeria. Energy Convers. Manag. 2014, 79, 431-440. [CrossRef]

56. Ishikawa, M.; Terauchi, M.; Komori, T.; Yasuraoka, J. Development of High Efficiency Gas Turbine Combined Cycle Power Plant. Mitsubishi Heavy Ind. Tech. Rev. 2008, 45, 15-17.

57. Larsson, E. Diagnosis and Supervision of Industrial Gas Turbines. Available online: https://www.vehicular. isy.liu.se/Publications/Lic/12_LIC_1528_EL.pdf (accessed on 24 February 2019).

58. Wu, X.; Shen, J.; Li, Y.; Lee, K.Y. Steam power plant configuration, design, and control. Wiley Interdiscip. Rev. Energy Environ. 2015, 4, 537-563. [CrossRef]

59. Electricity End Uses, Energy Efficiency, and Distributed Energy Resources Baseline: Industrial Sector Chapter. Available online: https:/emp.lbl.gov/sites/all/files/end_use_baseline-industrial_sector-final.pdf (accessed on 24 February 2019).

60. Gu, C.; Xie, D.; Sun, J.; Wang, X.; Ai, Q. Optimal Operation of Combined Heat and Power System Based on Forecasted Energy Prices in Real-Time Markets. Energies 2015, 8, 14330-14345. [CrossRef]

(C) 2019 by the authors. Licensee MDPI, Basel, Switzerland. This article is an open access article distributed under the terms and conditions of the Creative Commons Attribution (CC BY) license (http://creativecommons.org/licenses/by/4.0/). 